\title{
Floristic diversity of extensively used fresh meadows (6510) in the Wielki Łęg Obrzański complex
}

\author{
Agnieszka Anna Klarzyńska*, Anna Kryszak \\ Department of Grassland and Natural Landscape Sciences, Poznań University of Life Sciences, Wojska Polskiego 38/42, 60-627 Poznań, Poland
}

Abstract

One of the habitat types protected within the framework of the NATURA 2000 network due to the presence of species of European importance are fresh meadows from the Arrhenatherion alliance. The maintenance of their characteristic floristic composition depends on habitat conditions and extensive use, while any changes in this respect trigger succession transformations potentially threatening their nature value.

The aim of the study was to conduct nature and habitat valuation of one of the largest meadow complexes in the Wielkopolska region, i.e. Wielki Łęg Obrzański, which will make it possible to describe the preservation status of fresh meadows and their habitats.

Based on multifaceted analyses of 535 relevés made using the Braun-Blanquet method in the years 2006-2012 and representing the Arrhenatherion alliance, the phytosociological and botanical structure as well as constancy of species in individual variants (floristic types) were determined. Moreover, their habitat conditions were defined, i.e. soil moisture and nitrogen content using the index method according to Ellenberg, while laboratory methods were used to determine the content of organic matter, soil moisture as well as the contents of potassium, magnesium and phosphorus in soil.

Floristic composition of fresh meadows from the Arrhenatherion alliance differs due to high heterogeneity of habitat. The presence of fresh meadow phytocenoses both on dried organic soils (the driest forms of flood meadows) and on mineral soils (oak-hornbeam forests) contributes to differences in the floristic composition both in ryegrass meadows and grass-fescue meadows, mainly due to soil moisture and fertility as well as sward use type. This constituted the basis for the identification of lower syntaxonomic units in the internal structure of the plant associations. Five variants were distinguished in Arrhenatheretum elatioris, while the community of Poa pratensis-Festuca rubra was developed in as many as 8 variants.

Keywords: Arrhenatherion; fresh meadows; species diversity; habitat conditions; succession

\section{Introduction}

Fresh meadows from the Arrhenatherion alliance (Br.-Bl. 1925) Koch 1926 are some of the most diverse and common plant communities in Central Europe, including Poland [1-8]. This results first of all from the broad ecological scale of most species constituting these phytocenoses. They are highly variable plant communities whose floristic diversity is associated with the large extent of their habitat and use. Ryegrass meadows in their typical habitat, on moderately moist and relatively fertile soils, and with their extensive use (maximum two cuts) are characterized by an exceptionally high biodiversity, manifested in their high landscape value. Their sward is composed predominantly of tall grasses [mainly Arrhenatherum elatius (L.) P. Beauv. ex J. Presl \& C. Presl], which are accompanied by a numerous

\footnotetext{
* Corresponding author. Email: agnieszkaklarzynska@wp.pl
}

Handling Editor: Elżbieta Weryszko-Chmielewska group of dicotyledons with a considerable share of legumes $[9,10]$. In contrast, ryegrass-fescue meadows typically have a slightly poorer species composition. They develop most frequently on dried mineral and mucky peat soils. This plant community is composed of low grasses. In the last 25 years, in some European regions we have been observing a gradual disappearance of plant communities from the Arrhenatherion alliance, formerly developed in their typical form [11,12]. For this reason, restoring species-rich fresh meadows is at present a priority for conservation groups in central Europe $[13,14]$. The present, frequently depleted structure of Arrhenathereterum elatioris phytocenoses and the plant community Poa pratensis-Festuca rubra have been influenced first of all by the changes in their use, both its reduced management and its intensification, as well as changes in habitats; this also applies to other types of communities within the class Molinio-Arrhenatheretea $[15,16]$. The considerable drying of river valleys as a result of improperly operating drainage systems as well as floodings observed with increasing frequency in places where they have 

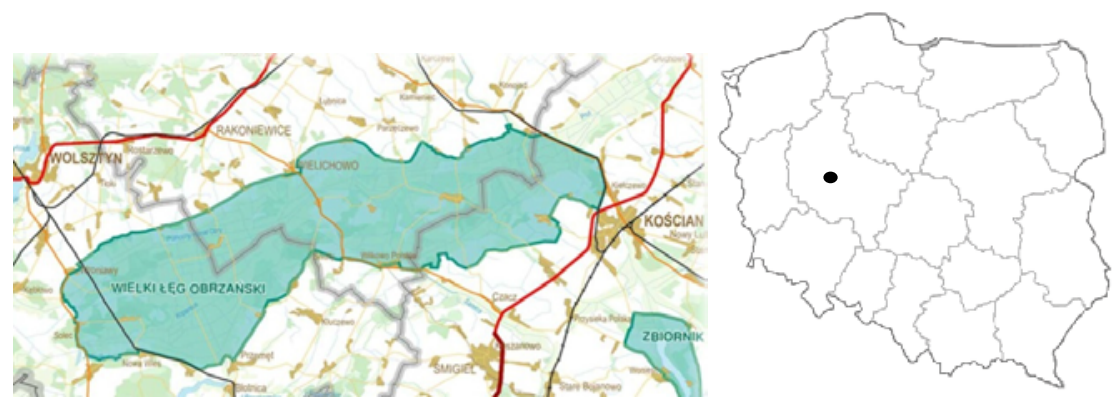

Fig. 1 Location of research area.

not occurred for many years are rapidly manifested in the condition of vegetation. This results in the transformation of numerous, previously not observed subassociations or floristic types of plant communities [17].

The aim of this study was to conduct a nature and habitat evaluation of one of the largest meadow complexes in the Wielkopolska region, i.e. Wielki Łęg Obrzański (Fig. 1), which will make it possible to specify the preservation status of fresh meadows and their habitats.

Wielki Łęg Obrzański (PLB300004) is an extensive meadow area located in the western part of the Wielkopolska region, protected as a NATURA 2000 area. It covers the widest section of the Obra Valley, crisscrossed by a dense network of canals and drainage ditches. The Central Obra Canal crosses it in the middle, while on the north the area is bordered by the Northern Obra Canal and in the south - by the Southern Obra Canal. In this area, in the last 15 years we have been observing a trend towards reduction in land use intensity, particularly in the area of the Southern Obra Canal where the proportion of small farms is greater. Typically 1-2 cuts are done during the growing season and frequently no fertilization is applied. Meadow plant communities from the Arrhenatherion alliance are used slightly more intensively on the Northern Obra Canal, where several larger dairy cattle farms are located.

\section{Material and methods}

The vegetation cover was analyzed and evaluated based on 535 relevés of plant communities from the Arrhenatherion alliance (Arrhenatheretum elatioris and the community Poa pratensis-Festuca rubra), using the Braun-Blanquet method, in the meadow complex Wielki Łęg Obrzański (WŁO) in the years 2006-2012.

Relevés were entered in the TURBOVEG data base. Using the JUICE software [18], a preliminary hierarchical classification analysis TWINSPAN [19] was performed. Further analysis was carried out using the NCLAS program of the SYNTAX 5.0 software package [20]. The relevés were classified twice, once on the basis of whether particular species were present, and once on the basis of their quantitative abundance. The similarity of the flora between the relevés was calculated using Jaccard's formula: $P=2 c / a+b \times 100 \%$, where: $P$ - similarity index; $c$ - the number of common species for both relevés; $a$ - the number of species in the first relevé; $b$ - the number of species in relevé $2,3,4, \ldots, n$.

On this basis, individual variants (floristic types) of plant communities were distinguished. The multifaceted nature valuation included the phytosociological structure of phytocenoses, constancy of species, the degree of cover in the phytocenosis surface area, biodiversity expressed in the number of species, and the Shannon-Wiener index $H^{\prime}, H^{\prime}=-\sum\left(p_{i} \times \ln p_{i}\right)$, where: $H^{\prime}-$ diversity index; $p_{i}$ - the ratio of the number of occurrence of a given species to the number of all occurrences of species $n_{i} / N ; n_{i}$ - the number of occurrences of $i$-th species in the phytosociological table; $\mathrm{N}$ - the number of occurrences of all species.

Syntaxa and the species characteristic for them were identified on the basis of Matuszkiewicz [21]. Vascular plants were identified in accordance with the nomenclature presented in Mirek et al. [22]

Habitat conditions of meadow communities were determined using the phytoindication method [23], assessing for each relevé: light conditions (L), moisture content $(\mathrm{F})$, nitrogen content $(\mathrm{N})$, and soil reaction $(\mathrm{R})$. Moreover, the following laboratory methods were used to determine: (i) soil moisture content - by gravimetry; (ii) content of organic matter in soil - by the weighing method consisting in sample roasting at a temperature of $600^{\circ} \mathrm{C}$ and calculation of weight losses; (iii) $\mathrm{pH}$ of soil in $1 \mathrm{~mol} \mathrm{KCl} \mathrm{\textrm {dm } ^ { - 3 }}$ - by potentiometry; (iv) contents of potassium (by flame photometry) and phosphorus (by colorimetry): in mineral soils - using the Egner-Riehm method, in organic soils in $0.5 \mathrm{~mol} \mathrm{HCl} \mathrm{dm}^{-3}$; (v) content of available magnesium: in mineral soils - by the Schachtschabel method, in organic soils in $0.5 \mathrm{~mol} \mathrm{HCl} \mathrm{dm}{ }^{-3}$.

The floristic and habitat analyses constituted the basis for the identification of succession directions for the characterized plant communities from the Arrhenatherion alliance in the Wielki Łęg Obrzański complex.

\section{Results}

The actually observed variation in the internal structure of phytocenoses from the Arrhenatherion association is the basis for distinguishing five variants (floristic types) within the Arrhenatheretum elatioris association and eight in the plant community Poa pratensis-Festuca rubra. 
Class: Molinio-Arrhenatheretea

Order: Arrhenatheretalia

Alliance: Arrhenatherion

Association: Arrhenatheretum elatioris

- typical variant (= Arrhenatheretum elatioris typicum)

- variant with Alopecurus pratensis (= A.e. alopecuretosum pratensis)

- variant with Deschampsia caespitosa (= A.e. deschampsietosum caespitosae)

- variant with Dactylis glomerata (= A.e. dactyletosum glomerate)

- variant with Armeria maritima (= A.e. armerietosum maritimae)

community Poa pratensis-Festuca rubra

- typical variant with admixture of Poa pratensis

- typical variant with admixture of Festuca rubra

- variant with Phalaris arundinacea

- variant with Deschampsia caespitosa

- variant with Alopecurus pratensis

- variant with Arrhenatheretum elatioris

- variant with Dactylis glomerata

- variant with Armeria maritima
In the areas covered by the characterized phytocenoses, typical plots predominate (Tab. 1). Among the relevés of the Arrhenatheretum elatioris association, they are distinguished by greater species richness (98 phytocenoses). On average 23.8 species were recorded per relevé. They include here hornbeam habitats, moderately moist, and the meadows are typically mowed twice during the vegetation season. The phytocenoses in question usually develop on mucky peats, frequently at a depth of approx. $0.5 \mathrm{~m}$, with underlying sand, with a groundwater level in July at a depth of 1.0-1.2 $\mathrm{m}$ below ground. Abundance of available forms of $\mathrm{Mg}, \mathrm{K}$ and $\mathrm{P}$ in soil is limited here (Tab. 2). They are phytocenoses with a relatively loose sward, with the mean cover index of 77.3\%. Apart from Arrhenatherum elatius, which covers here almost $48 \%$ of the phytocenosis area (Tab. 1), the highest constancy is observed for Achillea millefolium, Galium mollugo and Holcus lanatus (Tab. 3). Places with a higher moisture content, more abundant in nutrients, coming mainly from the mineralization process, and cut once start to be colonized by large quantities of Deschampsia caespitosa (L.) P.B. which eliminates other less expansive species, the trend which is in turn manifested in the mean number of species recorded in the relevés (19.8). The share of tall oat

Tab. 1 Floristic diversity and phytosociological structure of distinguished variants of plant communities from the Arrhenatherion alliance.

\begin{tabular}{|c|c|c|c|c|c|c|c|c|c|c|c|c|c|}
\hline \multirow[b]{2}{*}{ Variant of community: } & \multicolumn{5}{|c|}{ Arrhenatheretum elatioris } & \multicolumn{8}{|c|}{ com. Poa pratensis-Festuca rubra } \\
\hline & 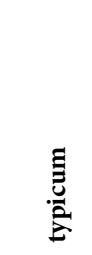 & 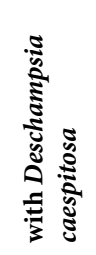 & 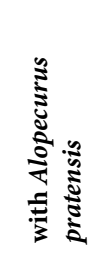 & 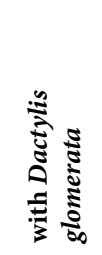 & 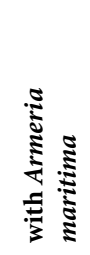 & 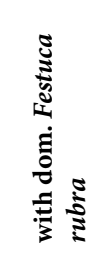 & 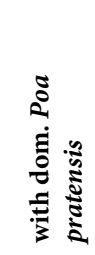 & 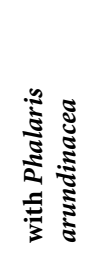 & 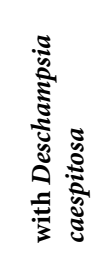 & 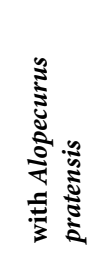 & 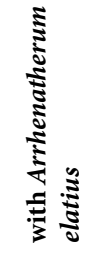 & 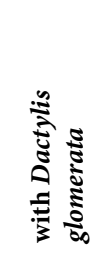 & 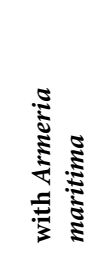 \\
\hline Relevé number & 98 & 18 & 31 & 25 & 23 & 43 & 170 & 17 & 66 & 6 & 16 & 12 & 17 \\
\hline Share of relevé (\%) & 18.1 & 3.3 & 5.7 & 4.6 & 4.2 & 7.9 & 31.4 & 3.1 & 12.2 & 1.1 & 3.0 & 2.2 & 3.1 \\
\hline Number of species & 151 & 82 & 107 & 113 & 88 & 131 & 170 & 83 & 120 & 66 & 84 & 72 & 104 \\
\hline Average number of species in relevé & 23.8 & 19.8 & 21.9 & 23.3 & 19.7 & 22.3 & 22.6 & 22.2 & 20.3 & 28.2 & 23.2 & 21.2 & 23.0 \\
\hline Average coverage sward/sodding (\%) & 77.3 & 76.1 & 78.2 & 80.6 & 73.2 & 78.1 & 81.6 & 80.6 & 77.3 & 83.3 & 82.2 & 82.1 & 77.1 \\
\hline Shannon-Wiener index & 1.85 & 1.70 & 1.78 & 1.84 & 1.72 & 1.86 & 1.86 & 1.76 & 1.76 & 1.74 & 1.76 & 1.73 & 1.81 \\
\hline \multicolumn{14}{|c|}{ Share (\%) of differential and characteristic species for: } \\
\hline Association/community & 47.8 & 36.8 & 37.4 & 38.6 & 37.4 & 49.6 & 47.1 & 35.4 & 37.6 & 33.6 & 40.7 & 31.6 & 31.8 \\
\hline O: Arrhenatheretalia & 14.6 & 12.9 & 12.5 & 24.1 & 8.5 & 13.2 & 14.0 & 6.0 & 7.6 & 14.6 & 35.1 & 37.8 & 7.5 \\
\hline O: Molinietalia & 1.9 & 18.3 & 11.3 & 3.0 & 3.0 & 5.0 & 4.9 & 10.9 & 26.9 & 29.2 & 5.3 & 2.3 & 5.7 \\
\hline $\begin{array}{l}\text { O: Trifolio fragiferae - Agrostietalia } \\
\text { stoloniferae + Plantaginetalia }\end{array}$ & 4.5 & 6.0 & 5.5 & 3.7 & 3.9 & 8.5 & 13.2 & 15.7 & 10.2 & 9.1 & 5.9 & 7.0 & 2.9 \\
\hline Cl. Molinio-Arrhenatheretea (other) & 22.1 & 18.7 & 21.9 & 19.8 & 25.4 & 14.2 & 10.8 & 4.1 & 9.5 & 1.4 & 7.7 & 9.9 & 14.0 \\
\hline Cl: Phragmitetea & 1.5 & 1.1 & 3.1 & 1.6 & 0.6 & 1.1 & 1.8 & 22.3 & 2.3 & 4.6 & 1.1 & 1.3 & 0.6 \\
\hline $\begin{array}{l}\text { Cl. Koelerio glaucae-Corynephoretea } \\
\text { canescentis }\end{array}$ & 1.0 & 0.3 & 1.9 & 0.8 & 8.1 & 1.1 & 0.7 & 0.0 & 0.2 & 0.1 & 0.3 & 0.1 & 18.5 \\
\hline companions & 6.7 & 5.9 & 6.4 & 8.5 & 13.2 & 7.4 & 7.5 & 5.6 & 5.6 & 7.4 & 4.1 & 10.1 & 19.1 \\
\hline Total & 100 & 100 & 100 & 100 & 100 & 100 & 100 & 100 & 100 & 100 & 100 & 100 & 100 \\
\hline
\end{tabular}


Tab. 2 Characteristics of soils covered by distinguished variants of plant communities from the Arrhenatherion alliance.

\begin{tabular}{|c|c|c|c|c|c|c|}
\hline & & & & Mg & $\mathrm{K}_{2} \mathrm{O}$ & $\mathbf{P}_{2} \mathbf{O}_{5}$ \\
\hline Variant of community & $\begin{array}{l}\text { Moisture } \\
\text { (\% weight) }\end{array}$ & $\begin{array}{c}\text { Soil pH (1 mol } \\
\mathrm{KCl})\end{array}$ & $\begin{array}{c}\text { matter content } \\
(\%)\end{array}$ & \multicolumn{3}{|c|}{$\left(\mathrm{mg} \mathrm{kg}^{-1}\right)$} \\
\hline \multicolumn{7}{|l|}{ Arrhenatheretum elatioris } \\
\hline typicum & 37.6 & 5.6 & 18.3 & 16.5 & 54.9 & 68.5 \\
\hline with Deschampsia caespitosa & 40.3 & 6.7 & 26.1 & 97.9 & 78.7 & 783.4 \\
\hline with Alopecurus pratensis & 71.3 & 5.6 & 31.9 & 40.1 & 85.8 & 114.5 \\
\hline with Dactylis glomerata & 58.8 & 6.1 & 27.9 & 134.1 & 399.3 & 2005.5 \\
\hline with Armeria maritima & 15.1 & 4.8 & 4.2 & 9.2 & 22.8 & 26.5 \\
\hline \multicolumn{7}{|c|}{ com. Poa pratensis-Festuca rubra } \\
\hline with dom. Festuca rubra & 16.0 & 6.0 & 4.6 & 41.1 & 89.1 & 156.9 \\
\hline with dom. Poa pratensis & 53.2 & 7.1 & 26.7 & 165.4 & 69.9 & 176.3 \\
\hline with Phalaris arundinacea & 63.9 & 5.6 & 54.4 & 146.7 & 71.4 & 1268.3 \\
\hline with Deschampsia caespitosa & 65.0 & 6.2 & 36.6 & 88.0 & 58.6 & 615 \\
\hline with Alopecurus pratensis & 71.0 & 5.9 & 32.2 & 311.2 & 135.3 & 1502.8 \\
\hline with Arrhenatherum elatius & 26.4 & 5.9 & 10.2 & 16.8 & 24.2 & 114.7 \\
\hline with Dactylis glomerata & 53.2 & 7.3 & 20.9 & 217.3 & 156.5 & 805.2 \\
\hline with Armeria maritima & 36.8 & 5.1 & 16.8 & 13.7 & 33.3 & 25.4 \\
\hline
\end{tabular}

Tab. 3 Stability of species within distinguished variants of plant communities from the Arrhenatherion alliance.

\begin{tabular}{|c|c|c|c|c|c|c|}
\hline \multirow[b]{2}{*}{ Variant of community } & \multicolumn{6}{|c|}{ Stability of species (\%) } \\
\hline & & $\mathbf{V}$ & IV & III & II & $\mathbf{I}$ \\
\hline \multicolumn{7}{|l|}{ Arrhenatheretum elatioris } \\
\hline typicum & 2.6 & Arrh.e., Ach.mil., Gal.mol., Hol.lan. & 2.6 & 4.6 & 7.9 & 82.1 \\
\hline with Deschampsia caespitosa & 6.1 & Arrh.e., Desch.c., Gal.mol., Fes.aru., Hol.lan. & 11.0 & 2.4 & 12.2 & 68.3 \\
\hline with Alopecurus pratensis & 6.5 & $\begin{array}{l}\text { Arrh.e., Alo.pra., Gal.mol., Hol.lan., Pla.lan., Ach. } \\
\text { mil., Rum.ace. }\end{array}$ & 3.7 & 7.5 & 11.2 & 71.0 \\
\hline with Dactylis glomerata & 4.4 & Arrh.e., Dac.glo., Rum.ace., Ach.mil., Tarax.off. & 4.4 & 8.8 & 14.2 & 68.1 \\
\hline with Armeria maritima & 4.5 & Arrh.e., Arm.mar., Rum.ace., Pla.lan. & 9.1 & 4.5 & 12.5 & 69.3 \\
\hline \multicolumn{7}{|c|}{ com. Poa pratensis-Festuca rubra } \\
\hline with dom. Festuca rubra & 2.3 & Fes.rub., Hol.lan., Gal.mol. & 5.3 & 5.3 & 15.3 & 71.8 \\
\hline with dom. Poa pratensis & 1.8 & Poa.pra.,Tarax.off., Ach.mil. & 3.5 & 7.1 & 7.6 & 80.0 \\
\hline with Phalaris arundinacea & 6.0 & Poa.pra., Phal.aru., Desch.c., Ran.rep., Pot.ans. & 3.6 & 16.9 & 18.1 & 55.4 \\
\hline with Deschampsia caespitosa & 1.7 & Poa.pra., Dech.c. & 7.5 & 5.8 & 10.0 & 75.0 \\
\hline with Alopecurus pratensis & 15.2 & $\begin{array}{l}\text { Poa.pra., Alo.pra., Ach.mil., Pha.aru., Fes.rub., } \\
\text { Arrh.e., Leo.aut., Desch.c., Pot.rep., Pol.per. }\end{array}$ & 10.6 & 19.7 & 18.2 & 36.4 \\
\hline with Arrhenatherum elatius & 4.8 & Poa.pra., Arrh.e., Tarax.off., Ach.mil. & 7.1 & 11.9 & 21.4 & 54.8 \\
\hline with Dactylis glomerata & 8.3 & $\begin{array}{l}\text { Poa.pra., Dac.glo., Lol.per., Ach.mil., Rum.ace., } \\
\text { Tarax.off. }\end{array}$ & 0.0 & 18.1 & 27.8 & 45.8 \\
\hline with Armeria maritima & 6.7 & $\begin{array}{l}\text { Poa.pra., Fes.rub., Gal.mol., Arrh.e., Arm.mar., Ach. } \\
\text { mil., Anthox.odo. }\end{array}$ & 3.8 & 7.7 & 12.5 & 69.2 \\
\hline
\end{tabular}


grass in the sward decreases, as it is replaced by species from the order of Molinietalia. In these phytocenoses, high constancy is reached by Deschampsia caespitosa, Festuca arundinacea Schreb., or Holcus lanatus.

In places where a high soil moisture is maintained over a longer part of the vegetation season (Tab. 2), the developing phytocenoses are associated with foxtail grass meadows the variant with Alopecurus pratensis. In their structure, an increased share was recorded both for species from the order Molinietalia and the class Phragmitetea (Tab. 1), while the highest constancy was observed here, apart from Arrhenatherum elatius, for Alopecurus pratensis L., Galium mollugo, Holcus lanatus, Plantago lanceolata L., and Rumex acetosa L. In localities typically slightly elevated and dried, on mineral soils, with a lower $\mathrm{pH}$ and a very low trophic level (Tab. 2), phytocenoses with a high share of Armeria maritima ssp. elongata Mill. Willd were observed (Tab. 1). They were characterized by a lower density of their swards, which was manifested in the mean vegetation ground cover of $73.2 \%$. Apart from species characteristic of the order Arrhenatheretalia and the class Molinio-Arrhenatheretea, their structure contained an increased share of species from the class Koelerio glaucae-Corynephoretea canescentis (Tab. 1).

In turn, the variant of A.e. with Dactylis glomerata developed on strongly decomposed peats and mucks with moderate soil moisture and much higher trophic levels in the habitats (Tab. 2), caused by regular fertilization.

The plant community Poa pratensis-Festuca rubra is typically characterized by a poorer species composition than ryegrass meadows (Tab. 1). Typical phytocenoses of this plant community developed here in two variants with the predominance of Poa pratensis (170 phytocenoses) or Festuca rubra (43 phytocenoses). The areas of the plant community with the predominant Poa pratensis cover slightly more moist and fertile habitats and are characterized by better covering levels in relation to those with the predominance of Festuca rubra. Apart from Poa pratensis, Achillea millefolium and Taraxacum officinale F.H. Wigg. are found with high constancy, while in phytocenoses with red fescue Holcus lanatus and Galium mollugo were recorded much more often (Tab. 3). The transition stage between ryegrass meadows and grass-fescue meadows is connected with the variant of the plant community Poa pratensis-Festuca rubra with Arrhenatherum elatius. It is a degradation form of the Arrhenatheretum elatioris association, which is classified to this plant community due to the small share of tall oatgrass in the sward, at a considerable proportion of species distinguishing the community Poa pratensis-Festuca rubra.

In the phytocenoses of meadow grass-fescue meadows formed at the most moist localities, occasionally fertilized and usually cut twice, greater numbers of Phalaris arundinacea specimens are recorded (17 phytocenoses), accompanied by the species found with high constancy, e.g. Ranunculus repens L. or Potentilla anserina L., or Alopecurus pratensis (6 phytocenoses). This was the basis to distinguish variants with Phalaris arundinacea and with Alopecurus pratensis, whose species composition comprised an increased share of species characteristic of the orders Molinietalia, Trifolio fragifereAgrostietalia stoloniferae and the class Phragmitetea. In similar habitats, but with their very limited use, on strongly loosened soils, Deschampsia caespitosa is found in huge numbers. As many as 66 areas of the plant community of P.p.-F.r. in the variant with Deschampsia caespitosa were recorded, which indicates the unfavorable direction of changes, leading to a depletion of the floristic composition of the plant community. Similarly as in the case of ryegrass meadows, this is manifested in the recorded lower mean number of species in phytocenoses (20.3) in comparison to the other variants (Tab. 1). In turn, fragments of grass-fescue meadows used as pastures show a tendency towards transformation into Lolio-Cynosuretum, which is reflected in the considerable share of highly productive grasses such as Dactylis glomerata and Lolium perenne. In contrast, in strongly dried and poor habitats Armeria maritima ssp. elongata and Anthoxanthum odoratum occur in very high numbers (Tab. 3), accompanied by less numerously represented grassland species from the class Koelerio glauca-Corynephoretea canescentis such as Festuca ovina L., Dianthus deltoides L., Trifolium arvense L., or Sedum acre L.

The principal component analysis (PCA) for the distribution of the main ecological and edaphic factors (Fig. 2, Fig. 3) shows the general habitat preferences of the distinguished subassociations, while the ranges for the moisture content index $(\mathrm{F})$ and soil nitrogen resources $(\mathrm{N})$, presented in Fig. 4, illustrate the ecological amplitude for the occurrence of phytocenoses of individual variants. The basic edaphic factor influencing heterogeneity of fresh meadows was associated with moisture content, which more markedly differentiates the association Arrhenatheretum elatioris (Fig. 2) than the plant community Poa pratensis-Festuca rubra (Fig. 3). In the case of ryegrass meadows, the moisture content factor makes it possible to distinguish the variant with Armeria maritima, while the variants with Deschampsia caespitosa and with Alopecurus pratensis are slightly less distinguishable. In grass-fescue meadows, their habitat moisture content plays the greatest role in the development of variants with Phalaris arundinacea, with Alopecurus pratensis as well as Armeria maritima.

In turn, the greatest effect on the development of variants with Dactylis glomerata is observed for the availability of nutrients and soil reaction. In lowland areas the light factor has no marked impact. A study by Zarzycki et al. [24] indicated a different situation in mountainous areas where light is a major ecological factor modifying the structure of fresh meadows. A considerable role is also played by soil reaction and fertility, while the effect of moisture content is slightly lesser.

This is confirmed by the main directions of transformations in plant communities of the Arrhenatherion alliance in the WŁO complex, established on the basis of the analysis of the phytosociological structure of the distinguished floristic variants and the results of habitat studies (Fig. 5).

\section{Discussion}

Meadow plant communities from the Arrhenatherion alliance (Br.-Bl. 1925) Koch 1926 are a threatened type of natural habitats in Poland, as has already been pointed out much earlier by Wojterska and Brzeg [25] as well as 


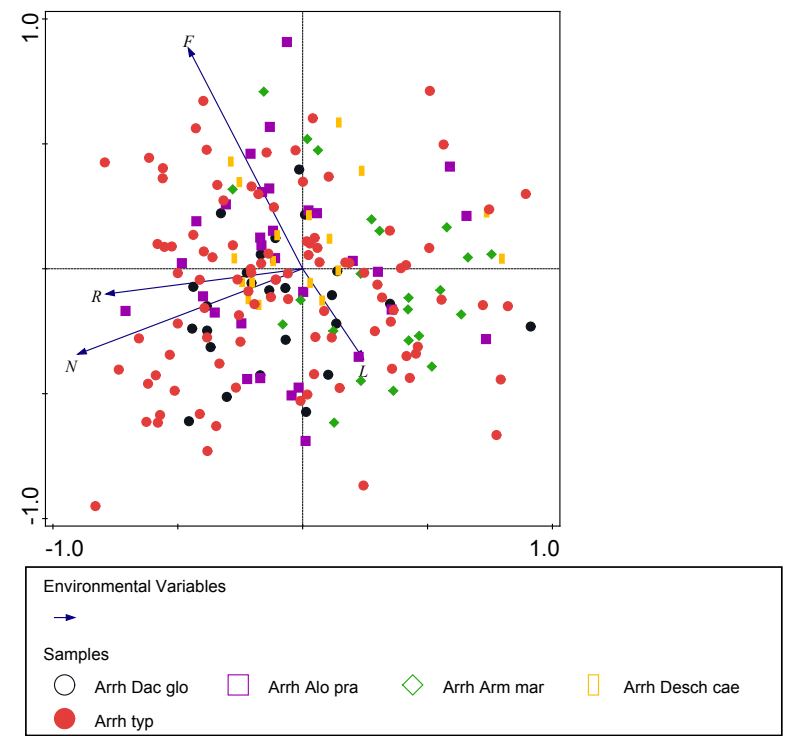

Fig. 2 Principal component analysis (PCA) - habitat variation in the association Arrhenatheretum elatioris (Br.-Bl. 1925) Koch.

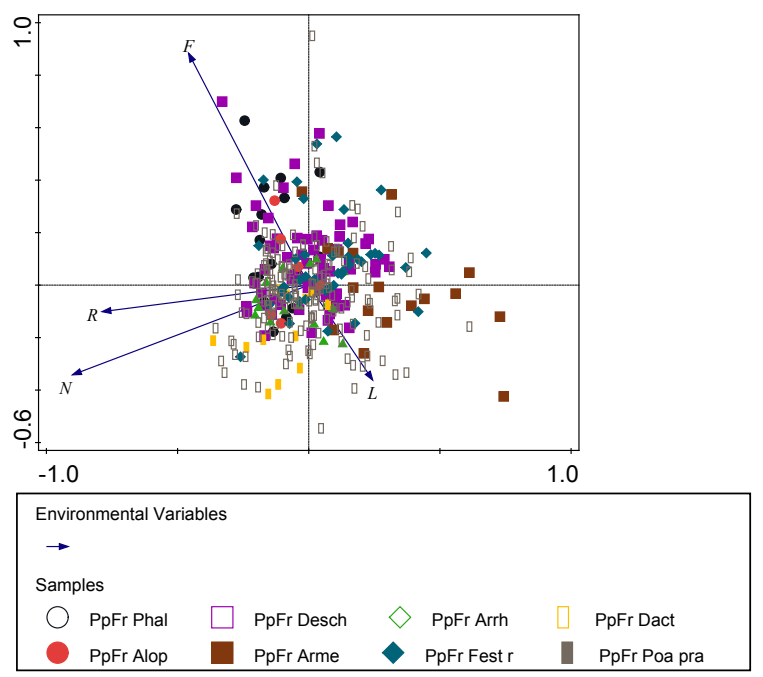

Fig. 3 Principal component analysis (PCA) - habitat variation in variants of the plant community Poa pratensis-Festuca rubra.

more recently by Zarzycki [26]. Such a situation is a consequence of two opposite trends. A decrease in profitability of agricultural production in small farms contributes to the negligence in tending of grassland, particularly regular mowing and fertilization. This results in the depletion of the floristic composition, primarily in ryegrass meadows, and the appearance of new, previously not observed variants or their transformation towards a poorer plant community Poa pratensis-Festuca rubra, which was also noticed in studies conducted in Serbia by Kojić et al. [27] and in the Czech Republic by Rozbrojova et al. [4]. In turn, the abandonment of the use of grass-fescue meadows typically leads to a slow encroachment of herbaceous plant communities and shrubs as the first stage in succession towards forest. The other opposite trend is associated with the replacement of small farms with conventional farming systems with large farms, which in turn is related to the substitution of extensively used meadows and pastures by species-poor plant communities of crops [28]. In such a case, grass-fescue meadows are typically transformed into ryegrass meadows, which is followed by the depletion of their species composition and highly productive grasses such as Dactylis glomerata, or Festuca pratensis start to predominate in the sward, which gave rise to the distinction of the variant with Dactylis glomerata [17,25]. The considerable floristic and habitat diversity is manifested in the numerous variants and subvariants distinguished by many authors. Within the association Arrhenatheretum elatioris, Nowiński [29] distinguished 14 subassociations, Grynia [9] 5 subassociations and 2 variants, Kucharski and Michalska-Hajduk [1] 16 subassociations, while Trąba [30] distinguished 8 natural and 7 anthropogenic variants. A slightly lesser variation, resulting mainly from the habitat moisture content, is observed in the plant community Poa pratensis-Festuca rubra [31]; as far as Wielki Łęg Obrzański is concerned, however, the composition and proportions of species allowed us to distinguish only 8 variants in this community.

The average numbers of species in the relevés of the communities Arrhenatheretum elatioris and Poa pratensis-Festuca rubra indicate that, compared to other areas of Poland, these values are lower especially in relation to ryegrass meadows $[17,32,33]$.

The high variability of meadow plant communities from the Arrhenatherion alliance frequently results in symptoms of degradation and in Wielki Łęg Obrzański they take fragmentary forms. The nature value, characteristic of the typical form, may be restored in some degraded areas. At present in Europe effective methods are searched for to restore the nature value of species-rich meadow communities, e.g. from the Arrhenatherion alliance [13,34-36]. One of the proposed solutions is to collect seeds or hay from donor localities, such as phytocenoses developed in the typical form with a considerable richness of species characteristic of the recreated plant community [37-39]. However, we need to take into consideration the fact that the success of restoration activity is often determined by the further management and condition of the habitat. These factors may limit the potential restoration of the typical floristic composition of these phytocenoses. An example in this respect may be provided by meadows from the Wielki Łęg Obrzański complex, where the use and first of all the rapidly progressing habitat changes connected mainly with the incorrectly operating system of canals and drainage ditches are the factors hindering the maintenance of stability in the species composition of the phytocenoses, constantly modifying them.

\section{Conclusions}

1. The high heterogeneity of habitats in the Wielki Łęg Obrzański complex, particularly in terms of soil moisture and soil nutrient availability, influences the variability in the internal structure of phytocenoses from 

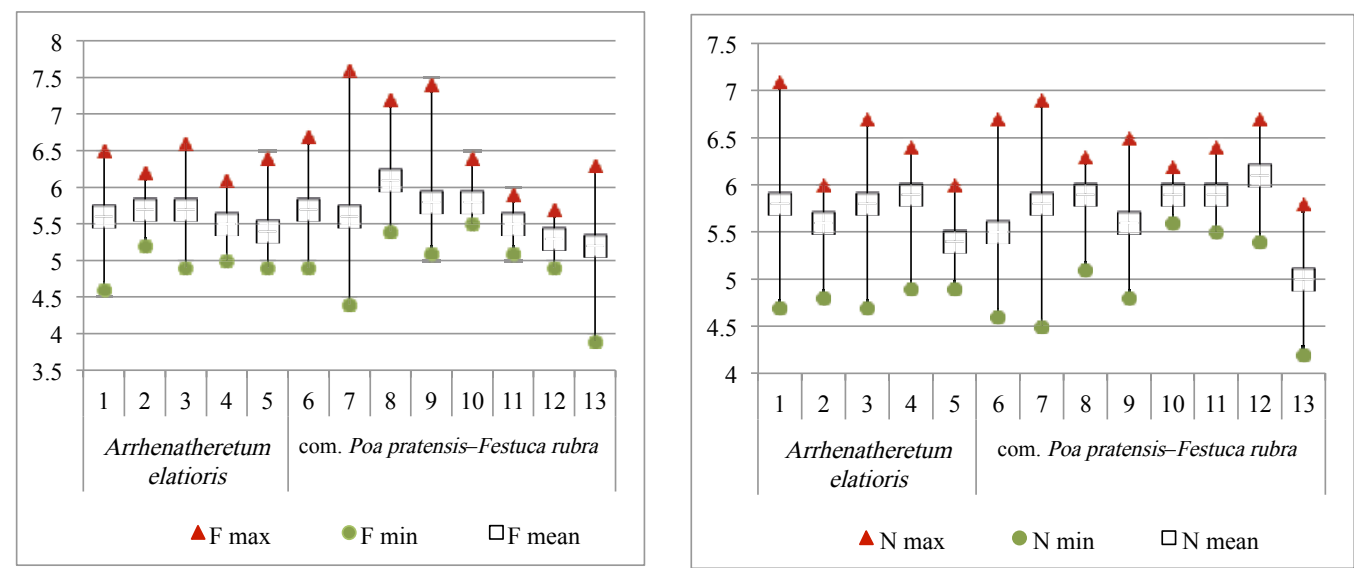

Fig. 4 Means and ranges of phytoindication indexes (Ellenberg values): $\mathrm{F}$ - moisture content and $\mathrm{N}$ - soil nitrogen resources for distinguished variants of plant communities from the Arhenatherion alliance. 1 - A.e. var. typicum; 2 - A.e. var. with Deschampsia caespitosa; 3 - A.e. var. with Alopecurus pratensis; 4 - A.e. var. with Dactylis glomerata; 5 - A.e. var. with Armeria maritima; 6 - P.p.-F.r. with dom. Festuca rubra; 7 - P.p.-F.r. with dom. Poa pratensis; 8 - P.p.-F.r. var. with Phalaris arundinacea; 9 - P.p.-F.r. var. with Deschampsia caespitosa; 10 - P.p.-F.r. var. with Alopecurus pratensis; 11 - P.p.-F.r. var. with Arrhenatherum elatius; 12 - P.p.-F.r. var. with Dactylis glomerata; 13 - P.p.-F.r. var. with Armeria maritima.

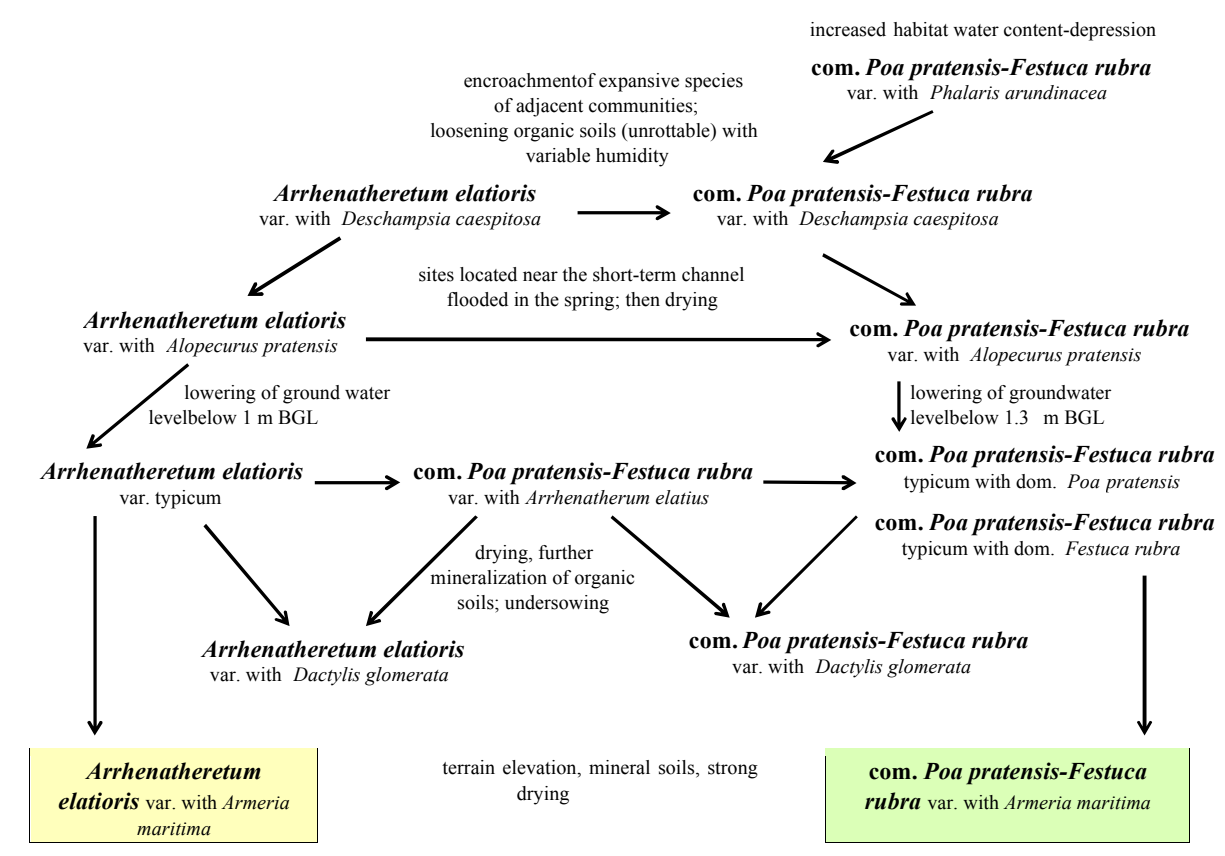

Fig. 5 Directions of transformations in meadow plant communities from the Arrhenatherion alliance in the Wielki Łęg Obrzański complex.

the Arrhenatherion alliance, which is manifested in the development of floristic types of fresh meadows:

a. the variant with Armeria maritima ssp. elongata with the presence of species characteristic of xerothermic meadows in loosened swards, mainly from the class Koelerio glaucae-Corynephoretea canescentis - at drying, with changes in soil structure, and nutrient deficits;

b. variants with characteristic species from the order Molinietalia and the class Phragmitetea - in small depressions with short-term spring floodings. This trend is manifested particularly in grass-fescue meadows.

2. The floristic composition of plant communities in the Arrhenatherion alliance in the Wielki Łęg Obrzański complex undergoes constant transformations, frequently deteriorating their nature value, and their restoration is limited by the existing use, primarily rapidly progressing changes in the habitat. 


\section{Acknowledgments}

The research was supported by the PhD research project (ID 42607). The title of the project: "Nature and use values of selected grassland communities in the Wielki Łęg Obrzanski” (competition No. 36).

\section{Authors' contributions}

The following declarations about authors' contributions to the research have been made: research designing: $\mathrm{AKl}, \mathrm{AKr}$; conducting experiments: $\mathrm{AKl}$; writing the manuscript: $\mathrm{AKl}, \mathrm{AKr}$.

\section{Competing interests}

No competing interests have been declared.

\section{References}

1. Kucharski L, Michalska-Hajduk D. Przegląd zbiorowisk łąkowych z klasy Molinio-Arrhenatheretea stwierdzonych w Polsce. Wiad Bot. 1994;38(1-2):95-104.

2. Dierschke H. Molinio-Arrhenatheretea - Kulturgrasland und verwandte Vegetationstypen - Teil 1: Arrhenatheretalia. Wiesen und Weiden frischer Standorte. Göttingen: Floristisch-Soziologische Arbeitsgemeinschaft; 1997. (Synopsis der Pflanzengesellschaften Deutschlands; vol 3)

3. Škodová I, Janišová M. The classification of Slovak grassland communities to the higher syntaxonomical units. Ann Bot (Roma). 2008;8:31-42.

4. Rozbrojová Z, Hájek M, Hájek O. Vegetation diversity of mesic meadows and pastures in the West Carpathians. Preslia. 2010;82:307-332.

5. Janišová M, Uhliarová E, Ružičková H. Expert system-based classification of semi-natural grasslands in submontane and montane regions of central Slovakia. Tuexenia. 2010;30:375- 422.

6. Valev N, Apostolova I, Rozbrojová Z. Alliance Arrhenatherion elatioris in west Bulgaria. Phytologia Balcanica. 2011;17(1):67-78.

7. Allegrezza M, Biondi E. Syntaxonomic revision of the Arrhenatherum elatius grasslands of central Italy. Fitosociologia. 2011;48(1):23-40.

8. Aćić S, Šilc U, Vrbničanin S, Cupać S, Topisirović G, Stavretović $\mathrm{N}$, et al. Grassland communities of Stol Mountain (eastern Serbia): vegetation and environmental relationships. Arch Biol Sci. 2013;65(1):211-227. http://dx.doi.org/10.2298/ABS1301211A

9. Grynia M. Charakterystyka geobotaniczna i znaczenie gospodarcze łąk rajgrasowych w Wielkopolsce. Zesz Probl Post Nauk Roln. 1987;308:81-86.

10. Kucharski L. Vegetation of oat-grass meadows in central Poland. Steciana. 2014;18(3):119-125. http://dx.doi.org/10.12657/steciana.018.013

11. Weigelt A, Weisser WW, Buchmann N, Scherer-Lorenzen M. Biodiversity for multifunctional grasslands: equal productivity in high-diversity low-input and low-diversity high-input systems. Biogeosciences. 2009;6(8):1695-1706. http://dx.doi.org/10.5194/bg-6-1695-2009

12. Vintu V, Samuil C, Rotar I, Moisuc A, Razec I. Influence of the management on the phytocoenotic biodiversity of some Romanian representative grassland types. Not Bot Horti Agrobot Cluj Napoca. 2011;39(1):119-125.

13. Haslgrübler P, Krautzer B, Graiss W. Germination capacity of threshed material from an Arrhenatherion meadow. In: Pötsch EM, Krautzer B, Hopkins A, editors. Grassland farming and land management systems in mountainous regions. Proceedings of the 16th Symposium of the European Grassland Federation, Gumpenstein, Austria, 29-31 August, 2011. Gröbming: Wallig Ennstaler Druckerei und Verlag Ges.m.b.H; 2011. p. 523-525. (Grassland science in Europe; vol 16).

14. Graiss W, Haslgrübler P, Blaschka A, Pötsch EM, Krautzer B. Establishment of an Arrhenatherion meadow through on-site threshing material and green hay transfer. In: Helgadóttir Á, Hopkins A, editors. The role of grasslands in a green future: threats and perspectives in less favoured areas. Proceedings of the 17th Symposium of the European Grassland Federation, Akureyri, Iceland, 23-26 June 2013. Reykjavík: Agricultural University of Iceland; 2013. pp. 341-343. (Grassland science in Europe; vol 18).
15. Stępień E. Changes of meadow flora species in area of Cedyński Landscape park. Pol J Environ Stud. 2009;18(6):1211-1215.

16. Kulik M. Changes of biodiversity and species composition of Molinia meadow depending on use method. Pol J Environ Stud. 2014;23(3):773-782.

17. Kucharski L. Roślinność łąkowa środkowej Polski na przełomie XX i XXI wieku - jej stan, kierunki zmian i ochrona. Ekologia i Technika; 2012;20(1):19-25.

18. Tichý L. JUICE, software for vegetation classification. J Veg Sci. 2002;13:451-453. http://dx.doi.org/10.1111/j.1654-1103.2002. tb02069.x

19. Hill M. Decorana - a FORTRAN program for detrended correspondence analysis and reciprocal averaging. Ecology and systematics. Ithaca, NY: Cornell University; 1979.

20. Podani J. SYN-TAX-pc. Computer Programs for Multivariate Data Analysis in Ecology and Systematics. Version 5.0 user's guide. Budapest: Scientia Publishing; 1993.

21. Matuszkiewicz W. Przewodnik do oznaczania zbiorowisk roślinnych Polski. Warszawa: PWN; 2012.

22. Mirek Z, Piękoś-Mirkowa H, Zając H, Zając M. Vascular plants of Poland: a checklist. Cracow: W. Szafer Institute of Botany, Polish Academy of Sciences; 1995. (vol 15).

23. Ellenberg H, Weber H, Dull R, Wirth V, Werner W, Paulissner D. Zeigerwerte von Pflanzen in Mitteleuropa. Scripta Geobotanica. 1992;18:5-25.

24. Zarzycki J, Kopeć M, Bedla D. Ocena zróżnicowania siedlisk użytków zielonych Pasma Radziejowej (Beskid Sądecki) metodą fitoindykacyjną. Fragm Agron. 2011;28(1):115-123.

25. Brzeg A, Wojterska M. Przegląd systematyczny zbiorowisk roślinnych Wielkopolski wraz z oceną stopnia ich zagrożenia. Badania Fizjograficzne nad Polską Zachodnią. Ser. B; 1996.45:7-40.

26. Zarzycki J. Łąki w polskich Karpatach - stan aktualny, zmiany i możliwości ich zachowania. Roczniki Bieszczadzkie. 2013;21:18-34.

27. Kojić M, Mrfat-Vukelić S, Dordević-Milošević S. Basic phytocenological and economical characteristic of meadows and pastures of Serbia. Biotechnology in Animal Husbandry. 2005;21(56):187-191. http:// dx.doi.org/10.2298/BAH0502187K

28. Dierschke H. Short survey of Arrhenatheretalia grassland in Germany. Ann Bot. 1999;57:7-14.

29. Nowiński M. Polskie zbiorowiska trawiaste i turzycowe. Warszawa: PWRiL;1967.

30. Trąba C. Florystyczna i rolnicza charakterystyka łąk i pastwisk w dorzeczu Łabuński. Rozp Nauk AR Lublin; 1994. (vol 163).

31. Herbich J, editor. Murawy, łąki, ziołorośla, wrzosowiska, zarośla. Poradniki ochrony siedlisk i gatunków Natura 2000 - podręcznik metodyczny. Warszawa: Ministerstwo Środowiska; 2004. (vol 3).

32. Kryszak A, Kryszak J, Klarzyńska A. Wpływ warunków siedliskowych i użytkowania na kształtowanie się Arrhenatherum elatioris. Woda Środowisko - Obszary Wiejskie. 2008;8:175-184.

33. Warda M, Stamirowska-Krzaczek E. Floristic diversity of chosen grass communities in the Nadwieprzański Landscape Park. Ann UMCS E. 2010;65:97-102. http://dx.doi.org/10.2478/v10081-010-0012-2

34. Hölzel N, Otte A. Restoration of a species-rich flood meadow by topsoil removal and diaspore transfer with plant material. Applied Vegetation Science. 2003;6:131-140. http://dx.doi.org/10.1111/j.1654109X.2003.tb00573.x

35. Walker KJ, Stevens PA, Stevens DP, Mountford JO, Manchester SJ, Pywell RV. The restoration and re-creation of species-rich lowland grassland on land formerly managed for intensive agriculture in the UK. Biol Conserv. 2004;119:1-18. http://dx.doi.org/10.1016/j. biocon.2003.10.020

36. Kiehl K, Kirmer A, Donath T, Rasran L, Hölzel N. Species introduction in restoration projects - evaluation of different techniques for the establishment of semi-natural grasslands in Central and Northwestern Europe. Basic Appl Ecol. 2010;11:285-299. http://dx.doi.org/10.1016/j. baae.2009.12.004 
37. Scotton M. Semi-natural grassland as a source of biodiversity improvement - SALVERE. Proceedings of the International Workshop of the SALVERE. Raumberg-Gumpenstein: Agricultural Research and Education Centre; 2009.

38. Nordbakken JF, Rydgren K, Auestad I, Austad I. Successful creation of species-rich grassland on road verges depend on various methods for seed transfer. Urban Forestry \& Urban Greening. 2010;9:43-47. http://dx.doi.org/10.1016/j.ufug.2009.10.004

39. Conrad M, Tischew S. Grassland restoration in practice: do we achieve the targets? A case study from Saxony-Anhalt/Germany. Ecol Eng. 2011;37:1149-1157. http://dx.doi.org/10.1016/j.ecoleng.2011.02.010

\section{Różnorodność florystyczna łąk świeżych użytkowanych ekstensywnie (6510) na Wielkim Łęgu Obrzańskim}

\section{Streszczenie}

Jednym z typów siedlisk przyrodniczych objętych ochroną w sieci NATURA 2000 ze względu na występowanie gatunków o znaczeniu europejskim są łąki świeże ze związku Arrhenatherion. Utrzymanie ich charakterystycznego składu florystycznego jest zależne od warunków siedliskowych i ekstensywnego użytkowania, a wszelkie zmiany tych czynników zapoczątkowują przekształcenia sukcesyjne mogące zagrażać ich walorom przyrodniczym

Celem pracy była ocena przyrodniczo-siedliskowa, która pozwoliła scharakteryzować stan zachowania łąk świeżych na jednym $\mathrm{z}$ największych kompleksów łąkowych w Wielkopolsce - Wielkim Łęgu Obrzańskim. Na podstawie wieloaspektowej analizy 535 zdjęć fitosocjologicznych wykonanych metodą Braun-Blanqueta w latach 2006-2012 reprezentujących związek Arrhenatherion określono strukturę fitosocjologiczną i botaniczną stałość gatunków w poszczególnych wariantach (typach florystycznych) Ponadto określono ich warunki siedliskowe: uwilgotnienie i zawartość azotu metodą wskaźnikową Ellenberga oraz metodami laboratoryjnymi zawartość materii organicznej, wilgotność, a także zawartość potasu, magnezu i fosforu w glebie.

Wykazano zróżnicowanie siedliskowe i florystyczne ocenianych fitocenoz. Występowanie płatów łąk świeżych zarówno na przesuszonych glebach organicznych (najsuchsze postaci łęgów) jak i na glebach mineralnych (grądy właściwe) przyczynia się do różnic w składzie florystycznym zarówno łąk rajgrasowych jak i wiechlinowo-kostrzewowych, głównie ze względu na warunki wilgotnościowe i żyzność gleb, ale także na użytkowanie runi. Dało to podstawy do wyodrębnienia w wewnętrznej strukturze zespołów niższych jednostek syntaksonomicznych. W Arrhenatheretum elatioris wyodrębniono 5 wariantów, natomiast w zbiorowisku Poa pratensis-Festuca rubra wyróżniono aż 8 wariantów. 